Int Arch Allergy Appl Immunol 1990;93:I-V

\title{
Contents, Vol. 93, 1990
}

\section{No. 1}

Original Paper

Immunology of Celiac Disease: Tissue and Species Specificity

of Endomysial and Reticulin Antibodies

Valeski, J.E.; Kumar, V.; Beutner, E.H.; Lerner, A.; Chor-

zelski, T.P 1

Density Distribution and Density Conversion of Neutrophils in Allergic Subjects

Miyagawa, H.; Okada, C; Sugiyama, H.; Hopp, R.J.; Agra-wal, D.K.; Nabe, M.; Gordy, C;

Bewtra, A.K.; Townley, R.G. 8

Immunization of Rabbits with Mosquito Bites: Immunoblot Analysis of IgG Antimosquito

Antibodies in Rabbit and Man

Brummer-Korvenkontio, H.; Lappalainen, P.; Reunala, T.;

Palosuo, T 14

Comparison of the Anaphylactoid Response Induced in Rats

by Castanospermine and Dextran

Doherty, N.S.; Beaver, T.H 19

Allergen-Induced Biphasic Bronchoconstriction in Rats

Watanabe, A.; Hayashi, H 26

T Lymphocyte Stimulation of Human Small Intestinal Glyco-protein Biosynthesis: Effects of Anti-CD 3 Antibody on Normal and Coeliac Mucosa

Crabtree, J.E.; Heatly, R.V.; Trejdosiewicz, L.K.; Losow-

sky, M.S 35

IgE-Binding Proteins from Pine (Pinus radiata D. Don) Pollen:

Evidence for Cross-Reactivity with Ryegrass (Lolium per-

enne)

Cornford, C.A.; Fountain, D.W.; Burr, R.G 41

Correlation between Lymphocyte Proliferative Responses and Dendritic Cell Migration in Regional Lymph Nodes following Skin Painting with Contact-Sensitizing Agents Kimber, I.;

Kinnaird, A.; Peters, S.W.; Mitchell, J.A. . . 47

T Cell Cytotoxicity in Cystic Fibrosis: Relationship to Pulmo

nary Status

Knutsen, A.P.; Mueller, K.R 54

Reactivity of Lymphoid Cells Isolated from the Tracheobron-

chial Lymph Nodes of Two Guinea-Pig Strains with High

or Low Susceptibility to Respiratory Anaphylaxis

Westphal Petersen, J.; Hasløv, K.; Lundberg, L.; Weis

Bentzon, M.; Gehring, T 59

Characterization and Quantification of Cellular Infiltrates in Nasal Mucosa of Patients with

Grass Pollen Allergy, Non-Allergic Patients with Nasal Polyps and Controls (With 1 color plate) 
Fokkens, W.J.; Holm, A.F.; Rijntjes, E.; Mulder, P.G.H.;

Vroom, T.M 66

Oxygen Radical Generation in Human Platelets: Dependence

on 12-Lipoxygenase Activity and on the Glutathione Cycle

Jahn, B.; Hänsch, G.M 73

Neutrophil Derived Interference in the Fluorometric Determi

nation of Histamine

Siegel, P.D.; Lewis, D.M.; Olenchock, S.A 80

Experimental Cedar Pollinosis in Rhesus Monkeys

Chiba, N.; Tamura, T.; Koizumi, K.; Tanigawa, M.; Shiba, M. 83

Possible Role of IL-6 in Pathogenesis of Immune Complex-

Mediated Glomerulonephritis in NZB/W Fl Mice: Induc

tion of IgE Class Anti-DNA Autoantibody Production

Mihara, M.; Ohsugi, Y

89

No. 2-3

Original Paper

Platelet-Activating Factor-Induced Activation and Cytoskele-

tal Change in Cultured Eosinophils

Ebisawa, M.; Saito, H.; Iikura, Y 93

Mast Cells in the Ovine Lower Respiratory Tract: Heterogeneity, Morphology and Density Chen, W.; Alley, M.R.; Manktelow, B.W.; Davey, P. . . 99

Site of Nonrestrictive Binding of SEA to Class II MHC Antigens Pontzer, C.H.; Russell, J.K.;

Jarpe, M.A.; Johnson, H.M. 107

Progesterone Triggers Selective Mast Cell Secretion of 5-

Hydroxytryptamine

Vliagoftis, H.; Dimitriadou, V.; Theoharides, T.C 113

Skin Reactivity to Substance P, Not to Neurokinin A, Is Increased in Allergic Asthmatics

Iwamoto, I.; Kimura, A.; Tanaka, M.; Tomioka, H.; Yoshi-

da, S 120

IV

Contents

Anti-Cephalexin Monoclonal Antibodies and Their Cross-Reactivities to Cephems and Penams Nagakura, N.; Shimizu, T.; Masuzawa, T.; Yanagihara, Y. 126 Neutral Endopeptidase Modulates Substance P-Induced Activation of Human Neutrophils

Iwamoto, I.; Kimura, A.; Yamazaki, H.; Nakagawa, N.;

Tomioka, H.; Yoshida, S 133

Effects of Ozone Exposure on Experimental Asthma in Guinea

Pigs Sensitized with Ovalbumin through the Airway

Sumitomo, M.; Nishikawa, M.; Fukuda, T.; Kaneko, T.;

Ikeda, H.; Suzuki, S.; Okubo, T

139

Induction of Eczematous Skin Reaction in Experimentally

Induced Hyperplastic Skin of Balb/C Mice by Monoclonal

Anti-DNP IgE Antibody: Possible Implications for Skin

Lesion Formation in Atopic Dermatitis

Katayama, I.; Tanei, R.; Yokozeki, H.; Nishioka, K.; Do- 
hi, Y 148

Expression of IgH Promoter/Enhancer Ly-1 Transgene in Hematopoietic Chimeric Mice Generated by Embryonic Stem

Cell Line (With 1 color plate)

Sumida, T.; Maeda, T.; Koike, T.; Tomioka, H.; Yoshida, S.; Taniguchi, M.; Rajewsky, K 155

Effects of a Single-Dose Pretreatment with Captopril on the

Immediate Response to Nasal Challenge with Allergen

Proud, D.; Naclerio, R.M.; Meyers, D.A.; Kagey-Sobotka,

A.; Lichtenstein, L.M.; Valentine, M.D 165

Mast Cells, Tissue Histamine and Eosinophils in Early- and

Late-Phase Skin Reactions: Effects of a Single Dose of

Prednisolone

Hammarlund, A.; Pipkorn, U.; Enerbäck, L 171

Mast Cell Activation by Hornet (Vespa orientalis) Venom

Barenholz-Paniry, V; Ishay, J.S.; Pick, LA.; Hammel, I. . 178 Role of Immunoglobulins Gl and

G2 in Anaphylactic Shock

in the Guinea Pig

Desquand, S.; Rothhut, B.; Vargaftig, B.B 184

Modulation of Rat Peritoneal Mast Cell and Human Basophil

Histamine Release by Estrogens

Cocchiara, R.; Albeggiani, G.; Di Trapani, G.; Azzolina,

A.; Lampiasi, N.; Rizzo, F.; Geraci, D 192

The Pathology of the Autologous Serum Skin Test Response in

Chronic Urticaria Resembles IgE-Mediated Late-Phase

Reactions

Grattan, C.E.H.; Boon, A.P.; Eady, R.A.J.; Winkelmann, R.K. 198 Increased Expression of

High-Affinity Low-Density Lipopro-

tein Receptors on Human T-Blasts

Huber, L.A.; Böck, G.; Jürgens, G.; Traill, K.N.; Schönit-

zer, D.; Wick, G 205

Ontogeny of Mast Cells in the Ventral Prostate of the Rat

Hammel, I.; Roizman, P.; Massas, R.; Abramovici, A. . 212 Lack of Correlation between Mast

Cell Response and Active

Anaphylaxis in Mice

Justus, D.E.; Lemmons, K.W.; Anderson, G.L 216

Immune Response to Endotoxin Isolated from Bacteroides

fragilis in the Pregnant Guinea Pig

Beckmann, L; Meisel-Mikolajczyk, F.; Leszczynski, P.;

Wallenburg, H.C.S 222

Generation and Metabolism of Leukotrienes in Granulocytes

of Patients with Cystic Fibrosis

Saak, A.; Schönfeld, W.; Knöller, J.; Steinkamp, G.; Hardt,

H. von der; König, W 227

Inhibition of Histamine Release from Rat Peritoneal Mast

Cells by MY-1250, an Active Metabolite of Repirinast 
(MY-5116)

Takei, M.; Endo, K.; Takahashi, K 237

Regulation of in vivo Expression of Fc Receptors for IgE

(FceR) on Murine Lymphocytes. II. Induction of FceR and

Its Inhibition in Mice Immunized with Antigen

Kiniwa, M.; Yanagihara, Y.; Tasaka, K 242

MTT Colorimetric Assay Detects Mitogen Responses of

Spleen but Not Blood Lymphocytes

Chen, C.-H.; Campbell, P.A.; Newman, L.S 249

Common German Cockroach Whole Body and Fecal Allergens: Immunoprint Inhibition Studies

Horner, W.E.; Kailas, L; Stankus, R.P.; Lehrer, S.B. ... 256

Alpha-Interferon Induces Cortisol Release by Human Adrenals in vitro

Cardoso, E.; Arzt, E.; Coumroglon, M.; Andrada, E.C.;

Andrada, J.A 263

CI-959, a New, Potential Antiallergic Drug, Inhibits Mediator Release from Lung and

Contractions of Human Airways in vitro

Adolphson, R.L.; Schellenberg, R.R.; Thueson, D.O.; Con-

roy, M.C 267

Involvement of Type I Hypersensitivity in Rapid Rejection of

Trichnella spiralis from Adult Rats

Zhang, S.; Castro, G.A 272

Short Communications

Disodium Chomoglycate Inhibits Immunoglobulin Produc

tion in vitro without Affecting Cell Growth in Human B

Cell Lines

Kimata, H.; Yoshida, A.; Ishioka, C; Mikawa, H 280

Presence of Autoantibody against Nasal Mucosal Cells in

Patients with Wegener's Granulomatosis

Kamitani, T.; Yuasa, K; Mori, S 282

No. 4

Original Paper

Immunoglobulin G Subclass Deficiency in Children with High

Levels of Immunoglobulin E and Infection Proneness

Loh, R.K.S.; Thong, Y.H.; Ferrante, A 285

Determination of Cow Milk Formula Allergenicity in the Rat

Model by in vitro Mast Cell Triggering and in vivo IgE

Induction

Fritsché, R.; Bonzon, M 289

Expression of Intercellular Adhesion Molecule-1 in Murine

Allergic Contact Dermatitis (With 1 color plate)

Goebeler, M.; Gutwald, J.; Roth, J.; Meinardus-Hager, G.;

Sorg, C 294

Effect of Locally Administered Heparins on Delayed-Type

Hypersensitivity Reactions

Kakakios, A.M.; Ryan, J.; Geczy, C.L 300

Contents 
Role of Mucosal Mast Cells in Intestinal Graft-versus-Host Reaction in the Mouse

Newlands, G.F.J.; Mowat, A.McI.; Felstein, M.V.; Miller,

H.R.P 308

Histamine Release from Cord Blood Basophils

Windelborg Nielsen, B.; Engberg, T.M.; Herlin, T.; Bjerke, T.; Schiøtz, P.0 314

How Similar Are in vitro Differentiated, Cord Blood Derived Eosinophils to Peripheral Blood Eosinophils? A Comparison of Their Peroxidase- and Eosinophil-Derived Neu-trotoxin Contents and of Their Responses to Various Activators

Bach, M.K.; Brashler, J.R.; Sanders, M.E.; Furitsu, T.; Ishi-

zaka, T323

Regulation of the Expression of the Low-Affinity IgE Receptor (FceRII) in the Human

Monocyte-Like Cell Line U-937 by Phorbol Esters and IgE

Pucillo, C; Salzano, S.; Pepe, S.; Vitale, M.; Formisano, S.;

Rossi, G $\quad 330$

Immunodetection Methods for Grass Pollen Allergens on

Western Blots

Ong, E.K.; Suphioglu, C; Singh, M.B.; Knox, R.B 338

Production of Superoxide Anion and Hydrogen Peroxide by

Human Neutrophilic Granulocytes during Chemotactic

Migration towards f-Met-Leu-Phe, C5a, Leukotriene B4,

Monocyte-Derived Chemotaxin/IL-8 and Platelet-Activat

ing Factor

Kownatzki, E.; Uhrich, S 344

T-Cell Responsiveness towards Various Synthetic Peptides of the P28 Antigen in Rat and Mouse

Models during Schisto-soma mansoni Infection

Wolowczuk, I.; Auriault, C; Gras-Masse, H.; Mazingue,

C; Vendeville, C; Tartar, A.; Capron, A 350

Differential Effect of Hypertonicity on FMLP-, Anti-IgE- and Ca2+ Ionophore A23187-Induced

Histamine Release from Human Basophil Leukocytes Tedeschi, A.; Arquati, M.; Lorini, M.;

Miadonna, A. . . . 359

Selective Inhibition by Magnosalin and Magnoshinin, Com

pounds from 'Shin-i' (Flos magnoliae), of Adjuvant-In

duced Angiogenesis and Granuloma Formation in the

Mouse Pouch

Kimura, M.; Kobayashi, S.; Luo, B.; Kimura, 1365

Tow-Dimensional Gel Electrophoretic Analysis of Kentucky

Bluegrass and Rye Grass Pollen Allergens. Detection with a

Murine Monoclonal Anti-Po $\alpha \mathrm{p}$ I Antibody and Amino

Terminal Amino Acid Sequence of Poa p I Allergen

Ekramoddoullah, A.K.M 371

Purification and N-Terminal Amino Acid Sequence of Two

Birch Pollen Isoallergens (Bet v I and Bet v II)

Elsayed, S.; Vik, H 378 
Author Index 385 